\title{
MEMOIR
}

\section{DAVID ALISON BROWN SCRIMGEOUR}

The path that led David Scrimgeour to the actuarial profession is now seldom if ever followed. He was an extremely able schoolboy and gained a scholarship to the Royal High School in Edinburgh, where his scholastic career fulfilled every expectation. There is little doubt that nowadays he would have gone on to university, where he might well have spent all his life as an academic of considerable distinction.

Fortunately, from the point of view of the profession, financial circumstances made this impossible and on leaving school in 1922 at age 17 he joined the staff of the Scottish Union and National Insurance Company and enrolled as a student of the Faculty of Actuaries. He made short work of the examinations and had to wait until he attained age 21 before he could be admitted as a Fellow of the Faculty. He became a Fellow of the Institute of Actuaries in 1930.

He moved to the Scottish Provident Institution in 1925 and remained there for the rest of his business life, a period of some 45 years. His abilities were soon recognised and he was appointed Assistant Actuary in 1930. Thereafter he held official positions of increasing seniority, culminating in his appointment as General Manager and Actuary in 1961, a position he held for nine years until his retirement in 1970 .

If his business career was distinguished, his service to the profession was even more so. There was no aspect of the profession's work with which he was not at one time involved. He held every major office within the Faculty, and if one mentions that these included Honorary Editor of the Transactions, Secretary and then Chairman of the Board of Examiners, and Honorary Treasurer, there can be no doubt as to the burdens he assumed. He was most fittingly elected President of the Faculty for 1960-62 and it will be noted therefore that he was holding that office when he took over the responsibilities of chief executive of his company.

But overriding all these professional and business achievements was the personality of the man. Above all, he was a great enthusiast; he never did anything by halves. In his youth he was a keen and successful soccer player. Later on, as many do, he turned to golf. The enthusiasm was the same, but the success was more intermittent. He was fond of reading; he was fascinated by history; he loved music. He was a regular performer at Scottish country dancing, a practice he continued at some danger to himself and to others almost to the end of his life. In his retirement he took up bridge.

His character and private life were exemplary, his marriage extremely happy. His wife Sally supported and encouraged him in every way. Her sudden death in 1990 was an immense loss to him, but, with typical determination, he insisted on remaining in their home by himself as long as he was able to do so, despite seriously failing eyesight. Sally and David had three talented daughters, and the progress of these daughters and in due course of their children was a source of much pride and pleasure to them.

Throughout his life David retained something of the academic - a quiet, humorous detachment which sustained him in good times and in bad. His abilities as an after-dinner speaker and versifier were legendary, and he gained a special niche in actuarial history of proposing in verse the toast to the decimal point at the Scottish Actuaries' Club in 1953 - a toast recorded in full in the minutes.

Within the last few weeks of his life he moved to Balnacarron House in St Andrews to be near his youngest daughter, Lindsay. He recalled that this had been the country home of Sir Robert Boothby, Manager of the Scottish Provident before the war, and that he had visited there as a young employee. He was to die there five days after his 92 nd birthday. He would have regarded this coincidence as worth a little smile. 